\title{
PENGEMBANGAN INDUSTRI RUMAH TANGGA (IRT ) GULA MERAH DI DESA KARYASARI PUPUAN TABANAN
}

\author{
N.N.C. Kusumawati ${ }^{1}$, I.W. Diara ${ }^{2}$, dan N.N. Yastini $^{3}$
}

\begin{abstract}
ABSTRAK
Pengabdian kepada masyarakat bertujuan untuk pengembangan potensi produksi gula merah di Desa Karyasari melalui peningkatan pendapatan masyarakat (kelompok Mutiara Merah). Metode yang diterapkan dalam pemberdayaan masyarakat pada kegiatan PKW sebagai berikut : (1) Koordinasi dan komunikasi secara partisipasi dengan masyarakat untuk merencanakan program melalui perencanaan, operasional dan evaluasi; (2) Penyuluhan untuk membangun persepsi dan pemahaman masyarakat mengenai inovasi atau program yang diterapkan; (3) Pelatihan iptek bagi masyarakat sasaran; (4) Pendampingan yaitu pertemuan secara berkala dan berkelanjutan antara pendamping dengan masyarakat sasaran sehingga iptek yang diberikan dapat dilaksanakan secara mandiri oleh masyarakat. Kegiatan yang dilakukan meliputi : Penyuluhan dan koordinasi kepada kelompok Mutiara Merah; Pelatihan membuat gula merah berbentuk cetakan kayu dan gula semut atau gula kristal; Pelatihan pengemasan (packaging); Pendampingan secara berkala dan berkelanjutan untuk meningkatkan produksi dan pemasaran. Hasil kegiatan pengabdian kepada masyarakat pada tahun kedua adalah Kelompok Mutiara merah di desa Karyasari Pupuan sudah bisa membuat dan mengemas gula merah berbentuk cetakan kayu dan gula semut.
\end{abstract}

Kata kunci : pengembangan, industri rumah tangga, gula merah, karyasari

\begin{abstract}
Community service aims to develop the potential for the production of brown sugar in Karyasari Village through increasing community income (Mutiara Merah group). The methods applied in community empowerment in PKW activities are as follows: (1) Coordination and communication in participation with the community to plan programs through planning, operations and evaluation; (2) Counseling to build community perceptions and understanding of innovations or programs implemented; (3) Science and technology training for target communities; (4) Assistance is a periodic and ongoing meeting between the facilitator and the target community so that the science and technology provided can be carried out independently by the community. Activities carried out include: Counseling and coordination with the Mutiara Merah group; Training in making brown sugar in the form of wood molds and palm sugar or crystal sugar; Training in packaging; Regular and on going assistance to increase production and marketing. The results of community service activities in the scond years were the Red Pearl Group in the village of Karyasari Pupuan, which was able to make and package brown sugar in the form of wooden molds.
\end{abstract}

Keywords: Development, home industry, brown sugar, Karyasari

\section{PENDAHULUAN}

\footnotetext{
${ }^{1}$ Fakultas Peternakan Universitas Udayana, candraasih@unud.ac.id

${ }^{2}$ Fakultas Pertanian Universitas Udayana, wayandiara@unud.ac.id

${ }^{3}$ Fakultas Pertanian Universitas Dwijendra, nengahyastini@gmail.com
} 
Desa Karyasari memiliki luas wilayah $12,70 \mathrm{Km}^{2}$ dengan 1.951 jiwa penduduk terdiri dari 967 laki-laki dan 984 perempuan. Desa Karyasari merupakan salah satu desa dari 23 desa yang menjadi Kawasan Pembangunan Prioritas Nasional (KPPN) di Kabupaten Tabanan. Pengembangan KPPN di Kabupaten Tabanan di arahkan kepada integrasi antara pertanian dengan pariwisata, yaitu melalui pengembangan desa wisata berbasis komoditas pertanian. Dalam pengembangan desa wisata, perlu dikembangkan atraksi wisata yang spesifik dan autentik/asli wilayah desa yang bersangkutan (Sardiana and Purnawan, 2017). Masyarakat lokal diharapkan menjadi pelaku utama dalam pengelolaan desa wisata, mulai dari perencanaan, pelaksanaan hingga evaluasi (sardiana and Purnawan, 2016; Purnawan and Sardiana, 2015).

Mata pencaharian masyarakat adalah bertani dan setiap KK memiliki 20 pohon aren yang sudah berumur diatas lima tahun (sudah berproduksi nira). Satu pohon aren dapat menghasilkan 10-20 liter nira/hari. Lima belas liter nira dapat menghasilkan $2 \mathrm{~kg}$ gula aren (merah) dengan harga Rp. $30.000 / \mathrm{Kg}$. Memperhatikan potensi tersebut maka di Desa Karya Sari diarahkan bagi pengembangkan produk gula nira yang selanjutnya akan diintegrasikan dengan pariwisata.

Proses pembuatan gula merah dari nira menjadi gula juruh (gula merah encer) dibutuhkan 6 jam perebusan (pemanasan) selanjutnya untuk menjadi gula yang siap dicetak memerlukan waktu 1 jam. Untuk membuat gula semut, petani meniris gula cetak dan dioven selama 7 jam baru siap dibungkus dan dipasarkan dengan harga Rp.40.000 sampai Rp. 50.000/ Kg. Kelompok Mutiara Merah sangat antusias untuk mengembangkan usahanya yang lebih efisien untuk mendapatkan hasil yang maksimal dengan kualitas yang lebih baik serta harga yang lebih mahal.

Berdasarkan permasalahan yang dihadapi kelompok mutiara merah, kami Tim PKW Unud bekerjasama dengan Pemda Tabanan dan Undwi Denpasar membantu dalam memberikan Teknologi pembuatan gula cetak dan semut (Kristal) yang lebih efisien dari segi waktu, tenaga, biaya dan kualitas yang lebih baik. Selanjutnya pendampingan kelompok mutiara merah, sehingga pengembangan usahanya semakin meningkat.

\section{METODE PELAKSANAAN}

Metode yang diterapkan dalam pemberdayaan masyarakat pada kegiatan PKW adalah sebagai berikut: (1) Koordinasi dan komunikasi secara partisipasif dengan kelompok tani masyarakat untuk merumuskan program mulai dari perencanaan, operasional dan evaluasi; (2) penyuluhan untuk mengembangkan persepsi dan pemahaman mengenai inovasi dan program yang diterapkan; (3) pelatihan dan simulasi terapan IPTEK yang diberikan kepada masyarakat; (4) Pendampingan antara pendamping dengan masyarakat sasaran sehingga untuk yang diberikan dapat dilaksanakan secara mandiri oleh masyarakat.

\section{HASIL DAN PEMBAHASAN}

Hasil dari kegiatan PKW di Desa Karyasari, Kecamatan Pupuan, Kabupaten Tabanan, dalam usaha pengembangan industri rumah tangga (IRT) gula merah (Kelompok Mutiara Merah) yaitu :

a. Sosialisasi kegiatan penyuluhan dan pelatihan pembuatan gula cetak dan semut kepada kelompok mutiara merah, yang bertempat di kantor Desa Karyasari.

b. Penyuluhan kepada kelompok mutiara merah, bertempat di kantor Desa Karyasari yang diikuti oleh 25 orang pengerajin gula. Materi yang diberikan adalah membuat gula merah bentuk centak dan gula semut. Pada kesempatan ini Tim PKW menyerahkan alat cetak gula dari aluminium yang diterima oleh Ketua Kelompok gula Mutiara Merah. 
c. Pelatihan membuat gula semut, diikuti oleh 20 peserta bertempat di rumah ketua kelompok Mutiara merah. Pelatihan diberikan oleh Ibu Dr. Ir. Luh Putu Wrasiati, MP dari FTP (Fakultas Teknologi Pertanian) Universitas Udayana.

Proses pembuatan gula cetak dan gula semut

Nira dipanen pada pagi hari langsung disaring dengan kain kasa atau kain kasa nyamuk untuk menghilangkan kotorannya.

Nira hasil saringan dimasukkan dalam wajan, dipanaskan dengan kompor selama 6 jam maka terbentuk gula juruh (gula merah cair).

Gula juruh masukkan dalam wajan, dipanaskan dengan kompor gas selama 1 jam. Selama pemanasan diaduk dengan sendok kayu terus menerus sampai menjadi pasta.

Gula yang seperti pasta dituangkan ke dalam cetakan baik kayu dan aluminium.

Gula dalam cetakan setelah dingin dilepas, selanjutnya siap dikemas dan dipasarkan dengan harga $40-50 \mathrm{ribu} / \mathrm{Kg}$.

Pembuatan gula semut yaitu lanjutan dari pembuatan gula cetak.

Nira sebanyak 15 liter yang sudah dipanaskan sampai menjadi gula merah seperti pasta ditambah 2 sendok gula pasir, diaduk dan dipanaskan dengan kompor gas dengan api yang kecil (suhunya diturunkan)sampai mengkristal kemudian ditumbuk lalu disaring dengan kain kasa.

Setelah gula disaring dioven selama 1 jam, selanjutnya didinginkan, dikemas dan dijual dengan harga Rp. 50.000/Kg.

Dari hasil pembuatan gula semut, kelompok mutiara merah sudah dapat menurunkan biaya produksi yaitu dengan menghemat waktu pengopenan dari 7 jam menjadi 1 jam. Hal ini memberikan efisiensi dari segi waktu, tenaga dan biaya gas (listrik).

d. Pendampingan dalam membuat sertifikat produk pangan industri.

Tim PKW membantu kelompok mutiara merah dalam proses pembuatan sertifikat produk pangan industri rumah tangga, pada saat ini kelompok mutiara merah sudah memiliki sertifikat yang berlaku sampai tahun 2023 .

e. Tim PKW melakukan pendampingan secara berkala untuk meningkatkan mutu produksi dan membantu pemasaran.

\section{KESIMPULAN}

Kegiatan yang sudah dilaksanakan dapat disimpulkan bahwa

1. Kelompok gula merah mutiara merah di Desa Karyasari sudah bias membuat gula cetak dan gula semut dengan biaya produksi menurun dan harga jual meningkat.

2. Kelompok Mutiara Merah sudah memiliki sertifikat produk pangan industri rumah tangga.

\section{UCAPAN TERIMA KASIH}

Penulis mengucapkan terimakasih kepada Kemenristekdikti atas dana yang diberikan lewat program PKW, Rektor Universitas Udayana, Ketua LPPM beserta Staf, terimakasih atas tenaga yang diberikan pada pelaksanaan di lapangan, sehingga pengabdian kepada masyarakat dapat berjalan sesuai rencana.

\section{DAFTAR PUSTAKA}

NLG Astariyani, IAL Dewi, IK Sardiana. 2019. Standarisasi dan Sertifikasi Pangan Industri Rumah Tangga (PIRT) untuk Peningkatan Daya Saing Produk Gula Aren di Kecamatan Pupuan Kabupaten Tabanan. Seminar Nasional Pengabdian Kepada Masyarakat (PKM) 1 (1), 747-751

Anon, 2014. Monografi Desa Sanda

Badan Statistik Kabupaten Tabanan Provinsi Bali. 2015. Kecamatan Pupuan dalam angka. 
Candraasih, K. N. N , I. W. Diara dan N. N. Yastini. 2018. Program Kementrian Wilayah Desa Karyasari dan Sanda Kecamatan Pupuan Kabupaten Tabanan Bali. Laporan Program Kemitraan Wilayah, Universitas UdayanaUnduwi dan Pemda Tabanan.

Purnawan, NLR., I.K Sardiana. 2017. Paket Wisata Edukasi Subak Upaya Menjaga Keberlanjutan Potensi Pertanian dan Pariwisata Berbasis Budaya di Bali. Jurnal Kawistara 7 (3), 275-284

Sardiana, IK., NLR Purnawan., 2016. Indigenous community, ecotourism and sustainability: Experience from Tenganan Dauh Tukad traditional. Heritage, Culture and Society: Research agenda and best practices in the hospitality and tourism ind | vol: | issue : | 2016-01-01 | Conference Proceedin

Sardiana, IK., NLR Purnawan. 2015. Community-based Ecotourism in Tenganan Dauh Tukad: An Indigenous Conservation Perspective. Jurnal Kajian Bali (Journal of Bali Studies) 5 (2), 347-368 